\title{
Membrane-Associated Ubiquitin Ligase SAUL1 Suppresses Temperature- and Humidity-Dependent Autoimmunity in Arabidopsis
}

\author{
Eva-Maria Disch, ${ }^{1}$ Meixuezi Tong, ${ }^{2}$ Tanja Kotur, ${ }^{1}$ Gerald Koch, ${ }^{3}$ Carl-Asmus Wolf, ${ }^{1}$ Xin Li, ${ }^{2}$ \\ and Stefan Hoth ${ }^{1}$ \\ ${ }^{1}$ Molekulare Pflanzenphysiologie, Biozentrum Klein Flottbek, Universität Hamburg, Hamburg, Germany; ${ }^{2}$ Michael Smith \\ Laboratories, University of British Columbia, Vancouver, British Columbia V6T 1Z4, Canada; ${ }^{3}$ Thünen-Institute of Wood \\ Technology and Wood Biology, Hamburg, Germany
}

Submitted 3 July 2015. Accepted 18 October 2015.

\begin{abstract}
Plants have evolved elaborate mechanisms to regulate pathogen defense. Imbalances in this regulation may result in autoimmune responses that are affecting plant growth and development. In Arabidopsis, SAUL1 encodes a plant U-box ubiquitin ligase and regulates senescence and cell death. Here, we show that saul1-1 plants exhibit characteristics of an autoimmune mutant. A decrease in relative humidity or temperature resulted in reduced growth and systemic lesioning of saul1-1 rosettes. These physiological changes are associated with increased expression of salicylic acid-dependent and pathogenesis-related $(P R)$ genes. Consistently, resistance of saul1-1 plants against Pseudomonas syringae pv. maculicola ES4326, P. syringae pv. tomato DC3000, or Hyaloperonospora arabidopsidis Noco2 was enhanced. Transmission electron microscopy revealed alterations in saul1-1 chloroplast ultrastructure and cell-wall depositions. Confocal analysis on aniline blue-stained leaf sections and cellular universal micro spectrophotometry further showed that these cell-wall depositions contain callose and lignin. To analyze signaling downstream of SAUL1, we performed epistasis analyses between saul1-1 and mutants in the EDS1/PAD4/SAG101 hub. All phenotypes observed in saul1-1 plants at low temperature were dependent on EDS1 and PAD4 but not SAG101. Taken together, SAUL1 negatively regulates immunity upstream of EDS1/PAD4, likely through the degradation of an unknown activator of the pathway.
\end{abstract}

In many plant cell types, tissues, and organs cell death is a fundamental process in differentiation, development, and stress responses. Initiation and execution of cell death are genetically regulated and tightly controlled at the molecular level. This is not only crucial for the formation and physiological function of tissues and organs but is also important in abiotic stress responses and in plant immunity (Coll et al. 2011; Gepstein and Glick 2013; Van Hautegem et al. 2015). Survival of plants following pathogen attack depends on elaborate immune responses. Pathogen-associated molecular patterns (PAMPs) are recognized by immune receptors at the plasma membrane that initiate downstream defense responses. Intracellular nucleotide binding and

Corresponding author: S. Hoth; E-mail: stefan.hoth@uni-hamburg.de

*The $\boldsymbol{e}$-Xtra logo stands for "electronic extra" and indicates that five supplementary figures are published online.

(c) 2016 The American Phytopathological Society leucine-rich repeat (NLR) receptor proteins activate a plethora of events upon recognition of pathogen effectors that have been delivered into the cytosol of plant host cells (Bent and Mackey 2007). Ultimatively, this results in a hypersensitive response (HR) that leads to cell death to confine pathogen spread to a few cells only (Jones and Dangl 2006).

Ubiquitination regulates various key events during pathogen attack and plant immunity. The ubiquitin (Ub)/proteasome pathway leads to the regulation or degradation of target proteins by achieving mono- or polyubiquitination, respectively. The activities of three types of enzymes, namely, E1 Ub-activating enzymes, E2 Ub-conjugating enzymes, and E3 Ub ligases, are fundamental for successful attachment of Ub moieties to their protein substrates. In some cases, E4 Ub ligase activity is required for efficient polyubiquitination. The pathway offers high specificity through recognition of target proteins by E3 Ub ligases, which represent one of the largest protein families in plants.

Components of the plant Ub/proteasome pathway have been shown to function as regulators of defense (Callis 2014; Dreher and Callis 2007; Vierstra 2009). The Ub-activating enzyme UBA1 that has been identified as a modifier of snc1 (MOS5) from a suppressor screen in the sncl nprl background is a positive regulator of plant resistance to pathogens (Goritschnig et al. 2007). Direct evidence for the contribution of E2 enzymes in plant defense is rare in Arabidopsis. However, the important role of various RING and U-box E3 Ub ligases in Arabidopsis immunity implies a function also of E2 enzymes. The RPM1interacting RING E3 Ub ligases RIN2 and RIN3 reside in the plasma membrane and contribute to NLR protein-dependent HR following infection with Pseudomonas syringae. However, pathogen growth was not altered in rin2 rin 3 mutants (Kawasaki et al. 2005). Plasma membrane-localized RING1/ATL55 is a positive regulator of cell death induced by the fungal toxin fumonisin B1 (Lin et al. 2008). The RING zinc finger protein ATL9 localizes to the endoplasmic reticulum and has Ub ligase activity. It has been suggested that ATL9 mediates chitindependent responses (Berrocal-Lobo et al. 2010). In contrast to these RING Ub ligases, the PUB Ub ligases involved in plant defense do not localize to membranes but, rather, to the cytoplasm or the nucleus (Cho et al. 2008; Drechsel et al. 2011; Samuel et al. 2008). A conserved role for PUB-ARM proteins in members of the Solanaceae and Brassicaceae has been proposed by identifying Arabidopsis PUB17 and its tobacco ortholog ACRE276 to be positive regulators of cell death and pathogen defense (Yang et al. 2006). The PUB-ARM Ub ligase triplet 
PUB22, PUB23, and PUB24 negatively regulates cell death and defense responses (Trujillo et al. 2008). In this triplet, PUB22 appears to have the most prominent role and affects PAMP-triggered immunity by marking components of the exocyst complex for degradation (Stegmann et al. 2012). The nuclear-localized Ub ligases MAC3A and MAC3B are part of the MOS4-associated complex (MAC) and are required for NLR protein-dependent pathogen resistance (Monaghan et al. 2009). Flagellin induces the association of flagellin receptor FLS2 (FLAGELLIN-SENISNG 2) with PUB12 and PUB13 (Li et al. 2012; Lu et al. 2011), which are PUB-ARM proteins promoting downregulation of FLS2 in the cytosol and, thereby, have a function in flagellin-induced immune responses.

The $\mathrm{Ub} /$ proteasome pathway is important in different aspects of effector-triggered immunity. The bacterial pathogen $P$. syringae secretes the effector AvrPtoB to the host cell that requires intrinsic Ub ligase activity to prevent host cell death. This strategy decreases plant immunity and is beneficial for pathogen fitness (Abramovitch et al. 2006; Janjusevic et al. 2006). The Xanthomonas campestris Ub ligase XopL specifically interacts with plant E2 enzymes (Singer et al. 2013). Agrobacterium tumefaciens, Ralstonia solanacearum, and poleroviruses use F-box protein effectors, which interact with plant Ub ligase complexes to reprogram the host cell Ub system (Angot et al. 2006; Pazhouhandeh et al. 2006; Schrammeijer et al. 2001; Tzfira et al. 2004). The rice pathogen Xanthomonas oryzae uses its effector $\mathrm{XopPX}_{\mathrm{oo}}$ to inhibit ligase activity of the plant U-box armadillo repeat (PUB-ARM) protein OsPUB44, which positively regulates immunity (Ishikawa et al. 2014). General inhibition of proteasome activity is achieved by the effectors XopJ and HopZ4 of Xanthomonas campestris and P. syringae, respectively. Both effectors interact with RPT6, a subunit of the 19S regulatory particle of the proteasome complex (Üstün et al. 2013, 2014).

It has been demonstrated recently, that plant NLR proteins are under tight control by the $\mathrm{Ub}$ /proteasome pathway to avoid accumulation of NLR proteins and, thus, autoimmune responses in the abscence of a pathogen challenge. The F-box protein CPR 1 (constitutive expressor of $P R$ genes 1 ) and the E4 Ub ligase MUSE3 (mutant, sncl-enhancing 3) facilitate polyubiquitination of NLR proteins (Cheng et al. 2011; Gou et al. 2012; Huang et al. 2014). In many Arabidopsis mutants, accumulation of NLR proteins such as SNC1 (suppressor of npr 1-1, constitutive 1) or RPS2 (resistance to $P$. syringae 2) results in autoimmune phenotypes. Autoimmunity is often characterized by macroscopic leaf lesions, enhanced pathogen resistance, and reduced growth. At the molecular level, constitutive immune responses include expression of defense marker genes such as $P R 1$ and $P R 2$ and increased levels of the plant defense hormone salicylic acid (SA). In some regards, the phenotype of saull (senescence-associated ubiquitin ligase 1) mutants, which lost the activity of the plasma membranelocalized SAUL1 (also called PUB44) protein and exhibit senescence and cell death phenotypes (Raab et al. 2009; Vogelmann et al. 2014), resembles characteristics of autoimmune mutants. SA levels and the expression of SA and defense genes were increased, and these phenotypes were PAD4-dependent (Vogelmann et al. 2012). Additionally, saull mutants showed reduced growth under nonpermissive conditions (Raab et al. 2009). However, the saull leaf yellowing phenotype occurred simultaneously throughout the whole leaf and was not characterized by the occurrence of local macroscopic lesions that were spread on the leaf. Thus, a clear function of the PUB-ARM Ub ligase SAUL1 in autoimmunity has not been established yet (Raab et al. 2009; Salt et al. 2011; Vogelmann et al. 2012). Here, we aim to investigate whether saull phenotypes depend on temperature or relative humidity or both and whether SAUL1 may have a function in autoimmunity, plant defense, or both.

\section{RESULTS}

The saul1-1 phenotype is dependent on temperature and relative humidity.

Previously, we found that early senescence and cell-death phenotypes of low light-grown saul1-1 mutants can be rescued in saul1-1 pad4 but not saul1-1 nprl double mutants (Vogelmann et al. 2012). This is reminiscent of Arabidopsis cell death or lesion mimic mutants and may suggest that physiological parameters other than photon flux density (PFD) affect saull phenotypes, in particular temperature and relative humidity (Gou et al. 2012; Hua et al. 2001; Jambunathan et al. 2001; Li et al. 2001; Yang and Hua 2004). At a PFD of $150 \mu \mathrm{mol} \mathrm{m} \mathrm{m}^{-2} \mathrm{~s}^{-1}$, $21{ }^{\circ} \mathrm{C}$, and 50 to $60 \%$ relative humidity, soil-grown saull mutants did not develop like wild type (WT) but showed systemic lesioning of leaves as well as reduced growth early in development (Raab et al. 2009). To test whether higher relative humidity and higher temperature affect saul1 phenotypes, WT and saull-1 plants were grown on soil at $24.2 \pm 0.3^{\circ} \mathrm{C}, 69.8 \pm 2.9 \%$ relative humidity, and $160 \mu \mathrm{mol} \mathrm{m} \mathrm{s}^{-1}$ in a growth chamber for $7,12,14$, and 17 days. Whereas saull-1 mutant plants were indistinguishable from WT at days 7, 12, and 14 (Supplementary Fig. S1), they showed some yellowing at the leaf edges at day 17 that was not observed in WT leaves (Fig. 1A and B).

Previously, we showed that, at the molecular level, occurrence of saull phenotypes was linked to the induction of marker genes for senescence, cell death, and defense (Raab et al. 2009; Vogelmann et al. 2012). To monitor the relevant marker gene expression, quantitative polymerase chain reaction (qPCR) experiments were performed on samples taken at days $7,12,14$, and 17. Expression of the senescence regulatory genes WRKY6 and AtNAP was almost unchanged at days 7 and 12 but slightly increased at day 14 (Fig. 1C and D). The increase in WRKY6 expression was still present after 17 days. A small but significant increase in the expression of the SA biosynthesis gene SID2 was observed at days 12 and 14, whereas the increase was larger at day 17 (Fig. 1E). In contrast, the expression of the SA signaling gene $P A D 4$ started to increase largely as soon as day 12 (Fig. 1F). An increased expression of the defense marker genes $P R 1$ and $P R 2$ was also seen at days 12, 14, and 17 (Fig. $1 \mathrm{G}$ and $\mathrm{H})$. As expected, expression in saul1-1 pad4-1 double mutants resembled the expression in WT plants for all genes tested (Fig. 1C to H) (Vogelmann et al. 2012)). saul1-1 pad4-1 and pad4-1 mutants were included in all subsequent experiments and resembled WT-like gene expression in all cases. Our data showed that higher relative humidity and higher temperature in the growth chamber could rescue saul1-1 phenotypes but not for the complete life cycle (day 17).

In many cases, high temperature is sufficient to fully prevent cell death and the underlying gene induction phenotypes of autoimmune mutants (Gou et al. 2012; Hua et al. 2001; Li et al. 2001; Yang and Hua 2004). We therefore increased the temperature to $25.6 \pm 0.6^{\circ} \mathrm{C}$ while keeping relative humidity and PFD unchanged. Under these conditions, saul1-1 and WT plants showed identical morphology (Fig. 2A). The increase in PAD4 and SID2 expression observed at $24.2^{\circ} \mathrm{C}$ (Fig. 1E and F) was completely abolished (Fig. 2B and C). Whereas a very small increase in $P R I$ expression was still visible, no change was observed in $P R 2$ expression (Fig. 2D and E). Note, that the scale for all gene expression analyses has been adopted from Figure 1. These results indicated that temperature is a key factor determining saull-1 morphology and molecular phenotypes and that, at $25.6^{\circ} \mathrm{C}$, cell death and defense responses are not turned on.

To test for the respective contribution of the three physiological parameters temperature, light, and relative humidity, we analyzed plant performance and gene expression after changing 
only one parameter at a time. While keeping PFD at $160 \mu \mathrm{mol}$ $\mathrm{m}^{-2} \mathrm{~s}^{-1}$ and higher temperature $\left(25.7 \pm 0.5^{\circ} \mathrm{C}\right)$, the relative humidity was lowered to $38.9 \% \pm 2.2 \%$. This decrease in relative humidity resulted in the occurrence of strong saull phenotypes before day 12 (Supplementary Fig. S2A). Plants were smaller than WT and showed yellowing of leaves. Therefore, samples were taken at day 11 to monitor changes in marker gene expression. As expected, expression of all marker genes, namely AtNAP, PAD4, SID2, PRI, and PR2 was increased. No significant increase was observed for WRKY6 (not shown). This indicated that the decrease of relative humidity from 71 to $39 \%$ resulted in cell death and lesion mimic phenotypes on the whole plant and at the molecular level, respectively.

To test for the relative contribution of temperature to saull phenotypes, the temperature was decreased to $20.5 \pm 0.5^{\circ} \mathrm{C}$. At this lower temperature, saul1-1 mutant plants did not develop properly but showed very early leaf yellowing and cell-death phenotypes at the young seedling stage (Supplementary Fig.
$\mathrm{S} 3$ ). To address expression changes, we grew plants at permissive conditions (PFD of $160 \mu \mathrm{mol} \mathrm{m} \mathrm{m}^{-2} \mathrm{~s}^{-1}, 24.4 \pm 0.7^{\circ} \mathrm{C}, 84.1 \% \pm$ $6.0 \%$ relative humidity) for 12 days before changing the temperature to $20.0 \pm 0.8^{\circ} \mathrm{C}$. Starting at 2 days after the temperature shift, saull-1 plants showed reduced growth and yellowing of leaves in contrast to WT and saull-1 pad4-1 plants (Fig. 3A). This was also reflected by decreased chlorophyll content and photochemical efficiency of photosystem II at lower temperature (Fig. 3F and G). Expression of the marker genes WRKY6, SID2, $P A D 4$, and $P R 1$ was already strongly induced in saull-1 plants at day 1 after the shift in temperature and stayed increased thereafter (Figs. 3B to E). Taken together, our physiological and gene expression analyses showed that high temperature and high relative humidity can suppress the saull-1 phenotypes.

To investigate the relative contribution of light to saull phenotypes, plants were grown at PFD lowered from $160 \mu \mathrm{mol}$ $\mathrm{m}^{-2} \mathrm{~s}^{-1}$ to $20 \mu \mathrm{mol} \mathrm{m} \mathrm{s}^{-1}$, while keeping temperature and relative humidity constantly high at $25.1 \pm 0.9^{\circ} \mathrm{C}$ and $70.3 \% \pm 2.7 \%$.
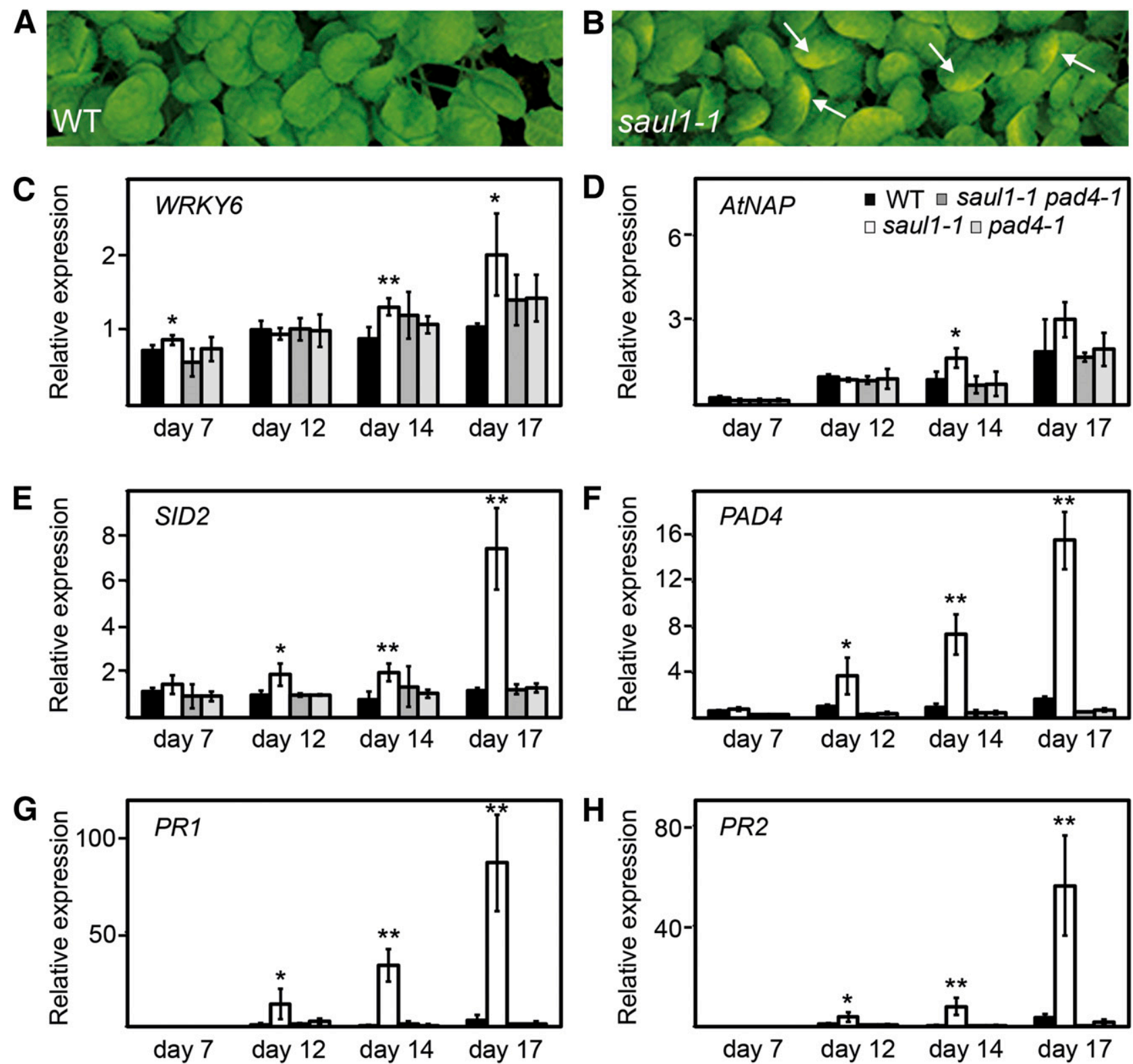

Fig. 1. Morphological and molecular phenotypes of saul1-1 mutants grown at high temperatures and high relative humidity. A and B, When grown for 17 days, saul1-1 plants showed some yellowing at the leaf edges (arrows) in contrast to WT plants. $\mathbf{C}$ to $\mathbf{H}$, Relative expression of the different senescence, cell death, and defense marker genes was measured in the indicated genotypes by quantitative polymerase chain reaction at days $7,12,14$, and 17 . Data represent mean \pm standard deviation $(n=4)$. Asterisks indicate significant differences analyzed by Student's $t$ test $\left({ }^{*} P<0.05, * * P<0.01\right)$. 
At day 7 after changing PFD, saull-1 mutants still resembled WT, indicating that low light could not induce autoimmunity at high temperature and high relative humidity (Supplementary Fig. S4).

\section{Chloroplast and cell-wall ultrastructure changes in saul1-1.}

The appearance of saull phenotypes resembled the appearance of chs 1 mutants in low temperature response and thus suggested that changes in chloroplast structure may coincide with the deterioration of saul1-1 plants (Wang et al. 2013; Zbierzak et al. 2013). We, therefore, analyzed chloroplast ultrastructure through transmission electron microscopy (TEM). Under permissive growth conditions of $24.4 \pm 0.7^{\circ} \mathrm{C}, 84.1 \% \pm$ $6.0 \%$ relative humidity, and a PFD of $160 \mu \mathrm{mol} \mathrm{m} \mathrm{s}^{-1}$ (Fig. 3), saul1-1 chloroplasts maintained the same ultrastructure as those of WT (Fig. 4A). Two to 3 days after changing the temperature to $20.0 \pm 0.8^{\circ} \mathrm{C}$ (Fig. 3), however, thylakoid membranes started to lose integrity. At day 2, the size of plastoglobules, particles consisting of proteins and lipids, started to increase (Fig. 4A), and an increase in the number of plastoglobules was observed starting at day 4 . All changes in ultrastructure that were initiated at day 2 or 3 were much stronger at 4 and 7 days after the shift in temperature (Fig. 4A to C). In addition to the ultrastructural changes in the chloroplasts, we observed changes in the ultrastructure of the cell wall (Fig, 4A, arrow). The observed depositions of material were significant already after 2 days and quite dramatic after 7 days. Quantification of the cell-wall thickness showed a 9.2-fold increase at the peak of deposition sites in saul $1-1$ cells $(2.59 \pm 0.79 \mu \mathrm{m}, n=13)$ compared with WT cells $(0.28 \pm 0.08 \mu \mathrm{m}, n=23)$ after 7 days (Fig. 4C).

The formation and deposition of callose and lignin may be the cause for such an increase in cell-wall thickness. We applied aniline blue staining and universal micro spectral photometry (UMSP) to detect these cell-wall components in tissue sections of, respectively, saull-1 and WT at day 7 after transfer to low temperature. In transmitted light, cell-wall increase was visible in saul1-1 but not in WT cells. Confocal laser scanning microscopy of aniline blue-stained sections indicated that callose was present in these thickened areas, whereas no signal was detected in WT (Fig. 5A). The analysis of tissue sections by UMSP showed that lignification, which is evidenced by the distinct UV-absorbances at a wavelength of $278 \mathrm{~nm}$, was also strongly increased in these cellwall deposits in saull-1 compared with WT (Fig. 5B). Depositions in saul1-1 samples revealed much higher distinct absorbance values than depositions in WT samples.

The saul1-1 phenotype is fully dependent on EDS1 and PAD4, but not SAG101.

The regulation of saull cell death and reduced growth phenotypes by temperature and relative humidity is reminiscent of



Fig. 2. Morphology and gene expression of saul1-1 mutants grown at permissive temperatures and relative humidity in a growth cabinet. A, At $25.6^{\circ} \mathrm{C}, 17$-dayold saul1-1 mutants completely resembled wild-type (WT) morphology. As controls, saul1-1 pad4-1 and pad4-1 plants are shown. B to E, Relative expression of the different marker genes was measured in the indicated genotypes by quantitative polymerase chain reaction at days 12 and 17 . Note that no difference between the indicated genotypes was observed. Data represent mean \pm standard deviation $(n=3$ to 4$)$. Asterisks indicate significant differences analyzed by Student's $t$ test $(* P<0.05)$ 
autoimmune mutants such as bonl and sncl. In these mutants, reduced growth and enhanced resistance phenotypes depend on EDS1 and PAD4 (Hua et al. 2001; Jambunathan et al. 2001; Li et al. 2001; Yang and Hua 2004). It has been shown previously that PAD4 is also crucial for saull-1 phenotypes (Vogelmann et al. 2012). PAD4 and EDS1 together with SAG101 form a regulatory hub in plant immunity (Wiermer et al. 2005). To determine the contribution of EDS1 and SAG101 to saul1-1
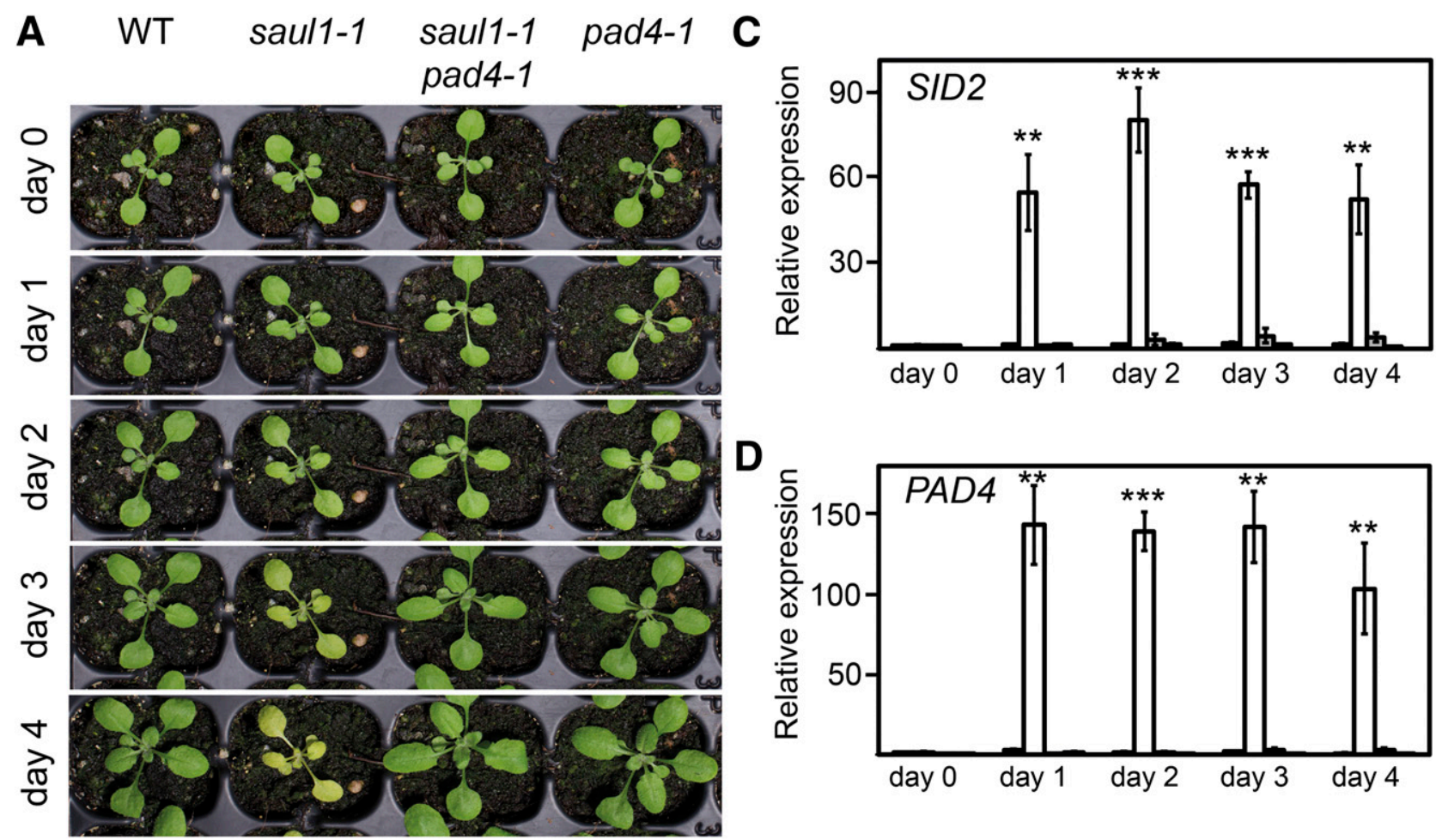

B
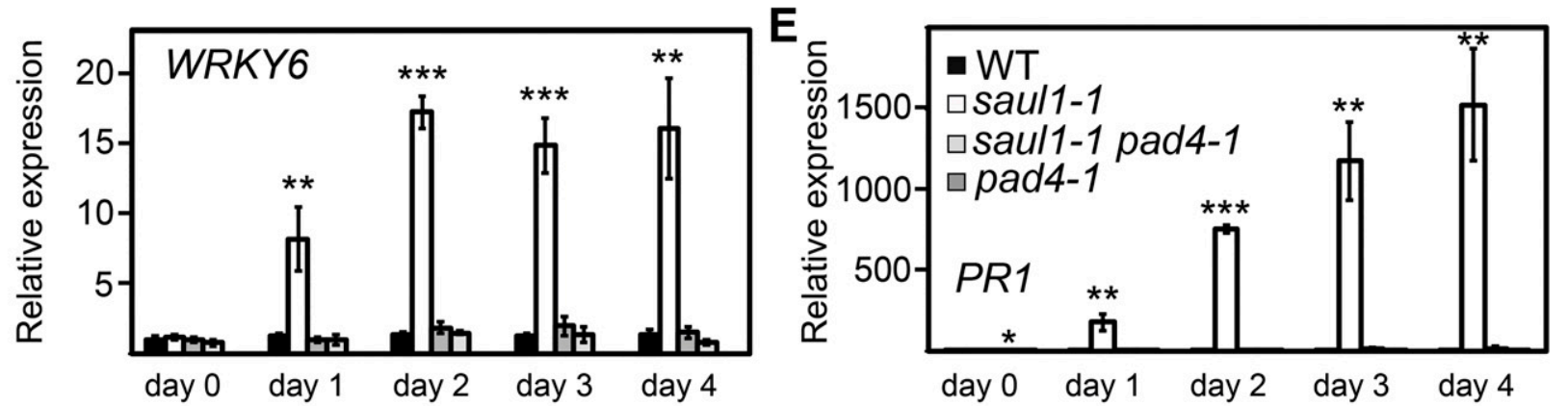

F

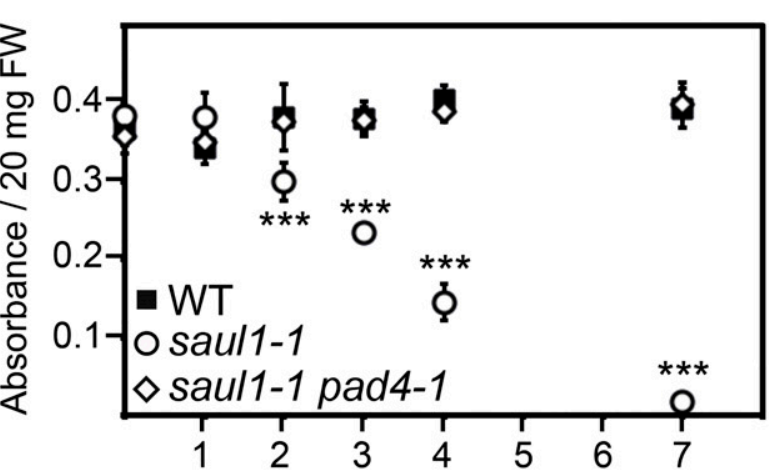

Days after temperature decrease

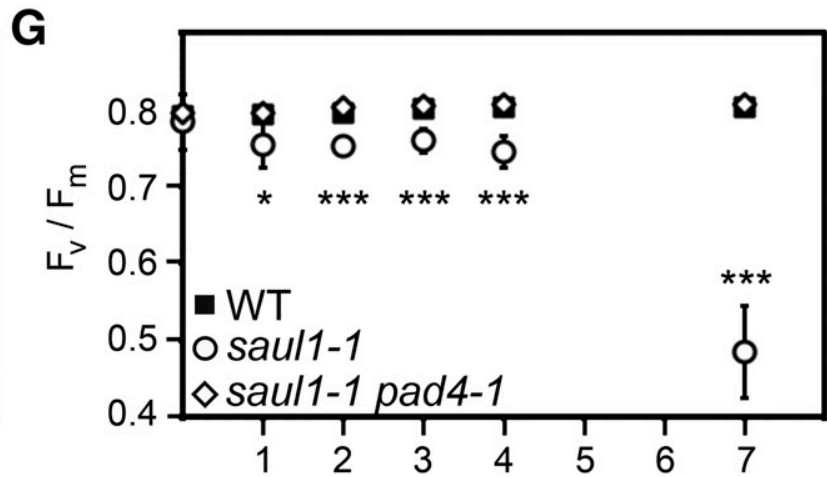

Days after temperature decrease

Fig. 3. Kinetic analysis of morphology, physiology, and gene expression changes in saul1-1 mutants following a decrease in temperature. A, A shift in temperature to lower values induced growth arrest and autoimmunity in saul1-1 but not in wild-type (WT), saul1-1 pad4-1, and pad4-1 plants. B to E, Relative expression of the different marker genes was measured in the indicated genotypes by quantitative polymerase chain reaction before (day 0 ) and after the decrease in temperature (days 1 to 4$)$. Note that all markers were induced in saull-1 plants starting at day 1 . Data represent mean $\pm \operatorname{standard~deviation~}(\mathrm{SD})(n=$ 3 to 4). F, Chlorophyll content of WT, saul1-1, and saul1-1 pad4-1 plants at the indicated time points was determined photometrically. Data represent mean \pm $\mathrm{SD}(n=3$ to 8 , except for saull-1 at day 3 with $n=2)$. G, Photochemical efficiencies of WT, saul1-1, and saull-1 pad4-1 plants are given as $\mathrm{F}_{\mathrm{v}} / \mathrm{F}_{\mathrm{m}}$ at the indicated days after temperature decrease. Data represent mean $\pm \mathrm{SD}(n=3)$. Asterisks indicate significant differences analyzed by Student's $t$ test $(* P<0.05$, $* * P<0.01, * * * P<0.001)$. 
phenotypes, saul1-1 eds1-2 and saul1-1 sag101-1 double mutants were generated and were grown side by side with saull-1 and saul1-1 pad4-1 plants at permissive conditions for 14 days, before lowering the temperature to $19.6 \pm 0.4^{\circ} \mathrm{C}$. Three days after the temperature shift, saul1-1 and saull-1 sag101-1 plants showed reduced growth and yellowing of leaves, whereas saull-1 eds1-2 and saul1-1 pad4-1 were like WT (Fig. 6A). This difference coincided with an increase in expression of PAD4 and PR1 in saul1-1 and saull-1 sag101-1 mutants, which was absent in saul1-1 eds1-2 and saul1-1 pad4-1 double mutant plants (Fig. $6 \mathrm{~B}$ and $\mathrm{C}$ ). These data showed that both PAD4 and EDS1 but not SAG101 are important regulators of saul1-1 phenotypes.

\section{saul1-1 mutants exhibit enhanced}

disease resistance phenotypes.

Suppression of saul1-1 phenotypes by pad4-1 and eds l-2 increased expression of defense marker genes, and the prominent regulation of saul1-1 by temperature suggested that SAUL1 may also affect plant immunity. To determine whether saull-1 mutants had altered resistance against virulent pathogens, saul1-1 and WT plants were challenged with virulent bacterial pathogens $P$. syringae pv. maculicola ES4326 and $P$. syringae pv. tomato DC3000, virulent oomycete Hyaloperonospora arabidopsidis Noco2, or avirulent P. syringae pv. tomato DC3000 AvrRps4, which can be recognized by RPS4. In all scenarios, resistance was enhanced in saull-1 plants. For bacterial infection, plants were grown at $28^{\circ} \mathrm{C}, 80 \%$ relative humidity, and a PFD of $90 \mu \mathrm{mol} \mathrm{m} \mathrm{m}^{-2} \mathrm{~s}^{-1}$. Growth at $28^{\circ} \mathrm{C}$ was intended to exclude any change in defense gene expression prior to infection. Very slight induction of the expression of $P R I$ or a few other defense genes has been observed in the absence of any morphological difference between WT and saul1-1 (Vogelmann et al. 2012) (Figs. 2, 3, and 5). At $28^{\circ} \mathrm{C}$ expression of the defense marker gene PRI was identical in saull-1 and WT (Supplementary Fig. S5). Infection was assayed at a standard temperature for $P$. syringae pv. tomato infection of $22^{\circ} \mathrm{C}$ (Brooks et al. 2004; Cheng et al. 2009). Temperatures below $24.2^{\circ} \mathrm{C}$ have been shown to induce immune responses in saull-1 (Figs. 1, 3, and 6)


saul1-1 pad4-1
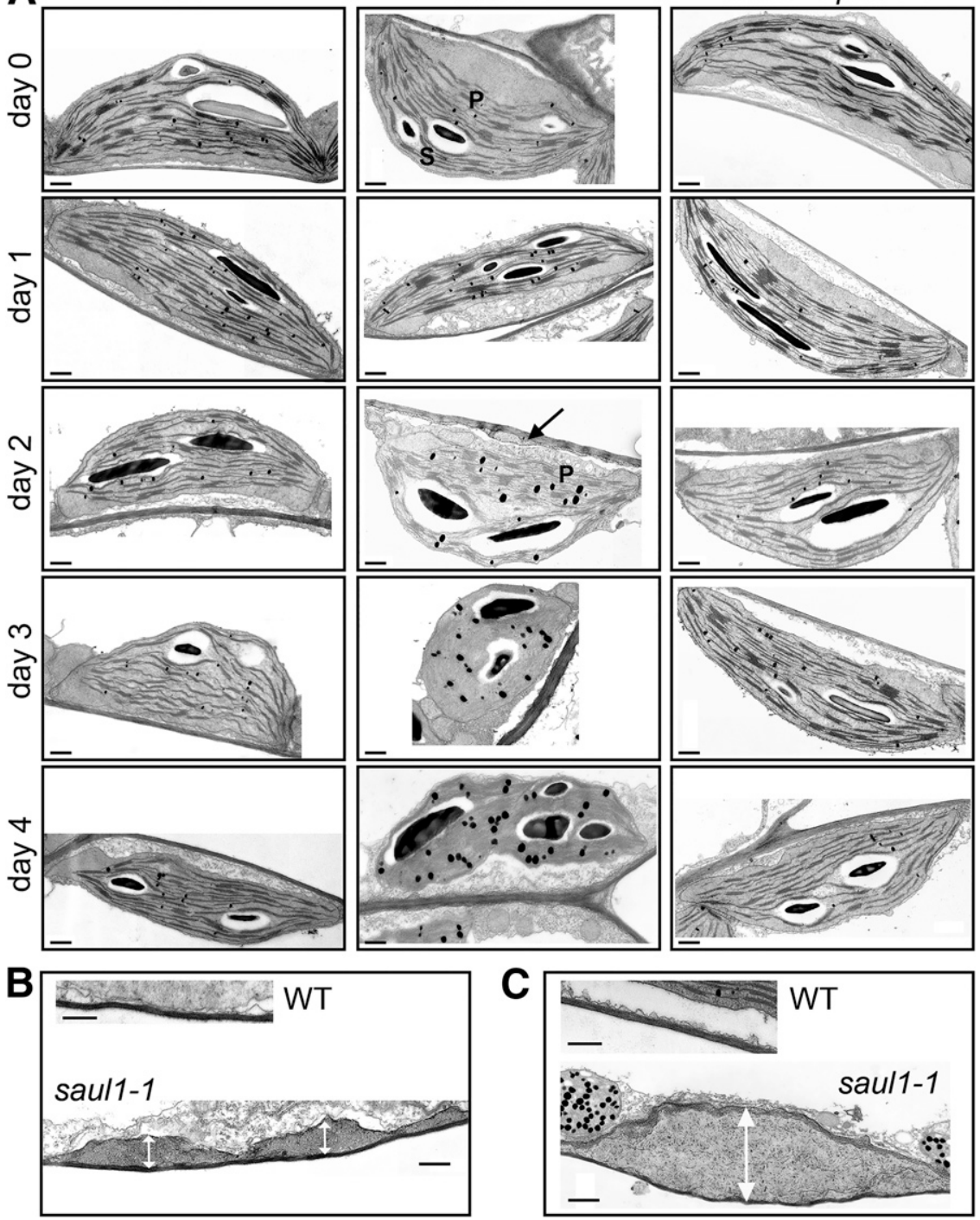

Fig. 4. Kinetic analysis of changes in ultrastructure of saul1-1 chloroplasts. A, The chloroplast ultrastructure was studied using transmission electron microscopy on leaf section of the indicated genotypes before (day 0) and after (days 1 to 4) a decrease in temperature. In saul1-1 but not in WT or saul1-1 pad4-1 plants, changes in the size and number of plastoglobules as well as changes in the cell wall (arrow) and in thylakoid membranes were observed. In saul1-1 sections at day 0, plastoglobules (P) and starch granules (S) have been labeled exemplarily for all panels. B and $\mathbf{C}$, Changes in cell-wall ultrastructure of saul1-1 leaf chloroplasts are shown, indicating cell-wall depositions (double arrows) in saull-1 plants 2 and 7 days (B and C, respectively) after the shift in temperature. Scale bars represent $0.5(\mathrm{~A}$ and $\mathrm{B})$ and $1.0 \mu \mathrm{m}(\mathrm{C})$. 


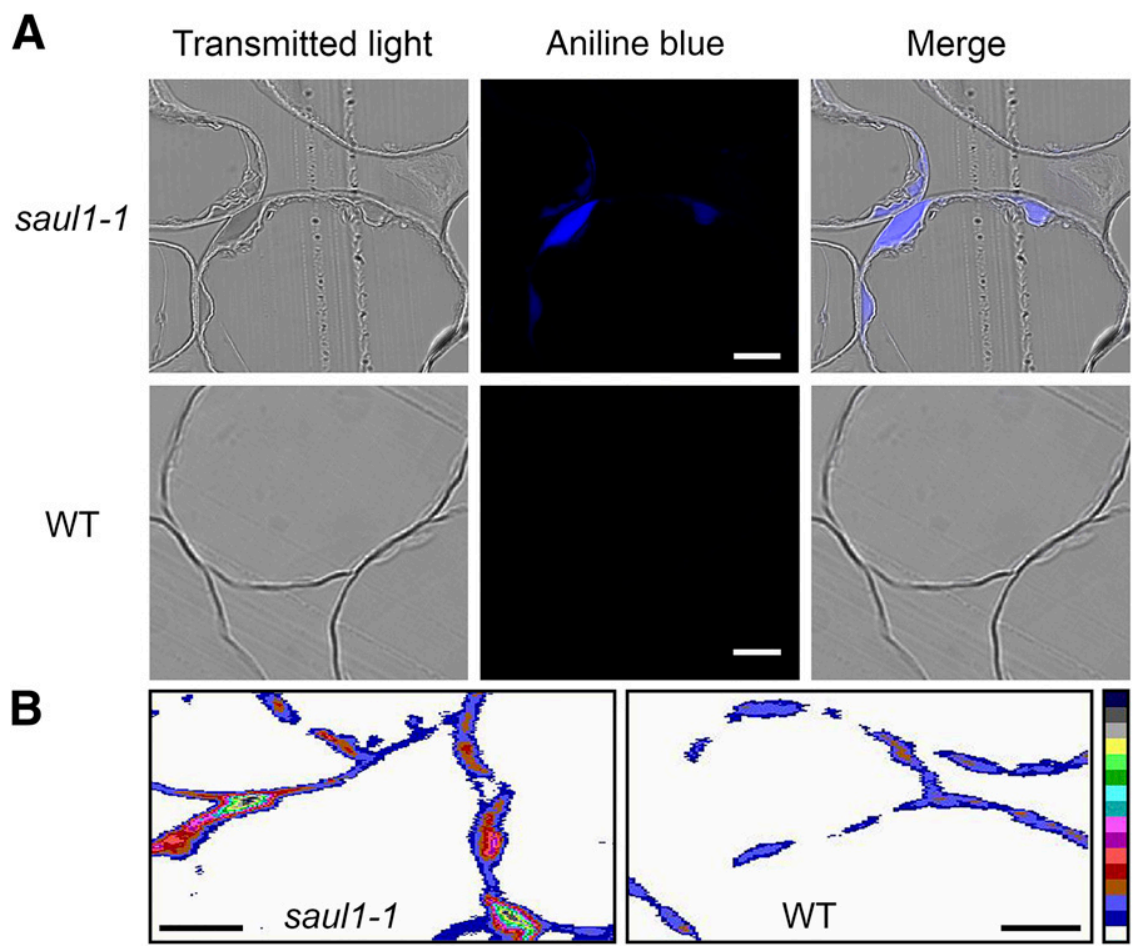

Fig. 5. Presence of callose and lignin in saull-1 cell-wall depositions. A, Cell-wall depositions in mesophyll cells of saul1-1 mutants (upper row) but not of wild type (WT) (lower row) were observed in transmitted light. Aniline blue-stained sections were analyzed by confocal laser scanning microscopy, and stained callose was detected as blue fluorescence signals. Merging of transmitted light and aniline blue pictures indicated the presence of callose in the cell-wall depositions of saul1-1 cells. B, Representative UV microscopic scanning profiles showing lignification of cell walls of mesophyll cells of the indicated genotypes. Color pixels represent different values of UV absorbance measured at $\lambda_{278 \mathrm{~nm}}$ with a resolution of $0.25 \times 0.25 \mu \mathrm{m}$. From bottom to top, the color bar at the right represents the following values: $<0.0506,0.0506,0.1128,0.1749,0.2371,0.2992,0.3614,0.4236,0.4857,0.5479,0.6100,0.6722,0.7343,0.7965$, $0.8587,>0.8587$. Scale bars represent $10 \mu \mathrm{m}$.

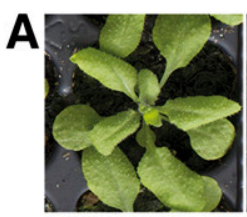

WT

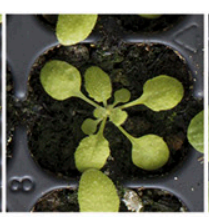

saul1-1



saul1-1

pad4-1

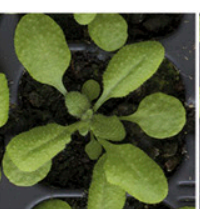

saul1-1

eds 1-2



saul1-1 sag101-1

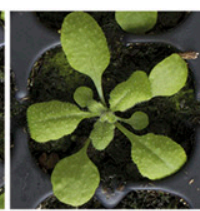

pad4-1

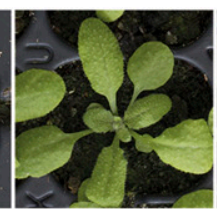

eds1-2

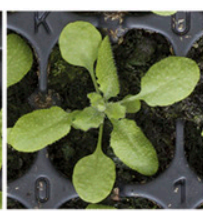

sag101-1
B

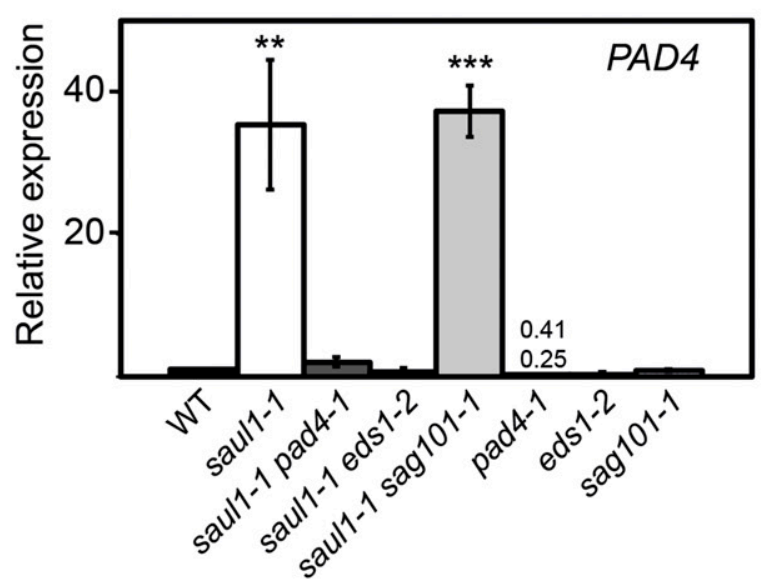

C

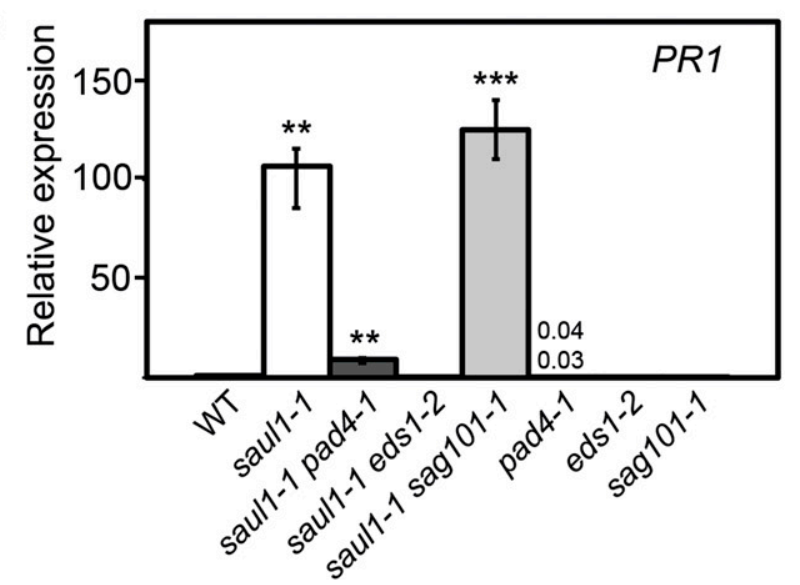

Fig. 6. Rescue of low temperature-triggered saul1-1 autoimmunity in saul1-1 pad4-1 and saul1-1 eds1-2. A, Plants with the indicated genotypes were grown in a growth cabinet for 14 days and were then challenged with $19.6^{\circ} \mathrm{C}$ for 3 days. Plants are shown at 17 days of age. B, Relative expression of $P A D 4$ was measured at day 3, following the temperature shift in the different genotypes by quantitative polymerase chain reaction (qPCR). C, Relative expression of $P R 1$ was measured by qPCR at day 3 following the temperature shift in the different genotypes. Data represent mean \pm standard deviation $(n=3$ to 4$)$ except for pad4-1 samples, as we only had measurements for two samples (both values indicated on top of the bar). Asterisks indicate significant differences analyzed by Student's $t$ test $(* * P<0.01, * * * P<0.001)$. 
(Raab et al. 2009). Bacterial growth of $P$. syringae pv. maculicola ES4326, $P$. syringae pv. tomato DC3000, and $P$. syringae pv. tomato DC3000 AvrRps4 was significantly lower on saul1-1 compared with WT plants (Fig. 7A to C). With $H$. arabidopsidis Noco2, seedlings were first grown at permissive conditions to allow normal growth of saull mutant, and infection was carried out at $80 \%$ relative humidity, $90 \mu \mathrm{mol} \mathrm{m} \mathrm{m}^{-2} \mathrm{~s}^{-1}$, and a temperature of $18^{\circ} \mathrm{C}$, leading to typical yellowing of saul1-1 plants. Almost no oomycete conidiospore growth was observed on saul1-1 seedlings (Fig. 7D). As expected, WT level of susceptibility was restored in saul1-1 pad4-1 and saul1-1 eds 1-2 plants. Taken together, saul1-1 exhibits EDS1/PAD4dependent enhanced disease resistance to pathogens, indicating that their visible and molecular phenotypes are reminiscent of autoimmunity.

\section{DISCUSSION}

Here, we present data on the role of a plasma membraneassociated PUB-ARM protein in plant immunity. Resistance to virulent pathogens, including the oomycete $H$. arabidopsidis Noco 2 and the bacteria $P$. syringae pv. maculicola ES4326 and $P$. syringae pv. tomato DC3000, was increased in saul1-1 plants (Fig. 7). Enhanced resistance was also observed for avirulent P. syringae pv. tomato DC3000 AvrRps4. At temperatures below about $25^{\circ} \mathrm{C}$ and at low relative humidity, saull-1 mutants showed autoimmunity (Figs. 1 and 2). A very small change in temperature from 25.6 to $24.2^{\circ} \mathrm{C}$ was sufficient to induce saul $1-1$ autoimmune responses. In addition, autoimmunity was suppressed in saul1-1 pad4-1 and saull-1 eds 1-2 mutants, indicating that PAD4 and EDS1 are crucial for saul1-1 autoimmunity. In contrast, SAG101 appeared not to be important (Figs. 3 and 6). Taken together, the saull phenotypes are reminiscent of those of other autoimmune mutants, such as sncl, bonl, and cprl (Gou et al. 2012; Hua et al. 2001; Jambunathan et al. 2001; Li et al. 2001; Yang and Hua 2004).

In saul1-1 leaf cells, two membrane-related processes could be observed. First, thylakoid membranes lost integrity from day 2 or 3 on after induction of saull-1 phenotypes by decreasing the temperature. This resulted in increased numbers of plastoglobuli, which also gained in size (Fig. 4). This is likely due to storage of chlorophyll and galactolipid degradation products in plastoglobuli (Lippold et al. 2012). Very similar observations have been made in recessive Arabidopsis chs $1-1$ autoimmune mutants that are affected in the toll interleukin 1 receptornucleotide binding site immune receptor gene CHS1 (chilling sensitive 1). In these mutants, chloroplast malfunctions preceded the occurrence of cell death (Wang et al. 2013; Zbierzak et al. 2013). It has been proposed previously that changes in chloroplast homeostasis and metabolism may be related to the activation of immune responses (Kachroo and Kachroo 2009; Nomura et al. 2012). In this context, it has also been shown that singlet oxygen, which is produced in chloroplasts to dissipate excess excitation energy, can lead to loss of chloroplast integrity and induce cell death resembling the local cell death of the HR in effector-triggered immunity (Kim et al. 2012; Wagner et al. 2004; Zurbriggen et al. 2009). The singlet oxygen-triggered cell death program in flu mutants was dependent on EDSI that

Fig. 7. Growth of Pseudomonas syringae pv. maculicola (P.s.m.) ES4326, P. syringae pv. tomato (P.s.t.) DC3000, P. syringae pv. tomato DC 3000 AvrRps4, and Hyaloperonospora arabidopsidis (H.a.) Noco2 on wild type (WT), saul1-1, saul1-1 pad4-1, saul1-1 eds1-2, pad4-1, and eds1-2 plants. A to $\mathbf{C}$, Leaves of plants, grown for 4 weeks at $28^{\circ} \mathrm{C}, 80 \%$ relative humidity, and a photon flux density of $90 \mu \mathrm{mol} \mathrm{m} \mathrm{m}^{-2} \mathrm{~s}^{-1}$, were infiltrated with $P$. syringae pv. maculicola $\mathrm{ES} 4326$, P. syringae pv. tomato DC3000, and P. syringae pv. tomato DC3000 AvrRps4, and CFU were determined at days 0 and 3 or 4 , respectively. Data represent mean \pm standard deviation (SD) ( $n=4$ to 5). D, For H. arabidopsidis Noco2, the number of spores was determined 7 days after spray-inoculation with an oomycete conidia spore suspension. Data represent mean \pm SD $(n=4)$. Generally, different superscripts indicate significant differences between different groups. Identical superscripts denote no significant differences. Data were analyzed using one-way analysis of variance (GraphPad Prism 6). 
was also required for low temperature-induced saull phenotypes (Fig. 6) (Ochsenbein et al. 2006).

Second, at day 2, changes at the cell wall started to be established that led to dramatic deposition of biomaterials (Fig. 4B and C). By using different imaging techniques, we showed that callose depositions and lignin were found in these thickened cell walls of saull-1 leaves (Fig. 5). The cell wall has previously been linked to biotic stress signaling (Hamann 2015; Malinovsky et al. 2014). Aberrant deposition of lignin follows the reduction of cellulose content by specific inhibitors or by mutations in cellulose biosynthesis genes. This has previously been described for mutants that affect the cellulase synthase gene CESA3. These mutations resulted in decreased cellulose synthesis, whereupon lignin synthesis and defense responses were induced (Caño-Delgado et al. 2003; Ellis et al. 2002). In many cases, pathogen infection induces the formation of papillae, cell-wall thickenings at the site of infection that contain callose and also lignin (Ellinger et al. 2013; Malinovsky et al. 2014; Nishimura et al. 2003; Underwood 2012). The altered structure and components of cell walls of saull plants could be partly responsible for its enhanced resistance phenotypes.

The Ub ligase SAUL1 appears to be important for immune responses initiated at the plasma membrane. Other factors of plant autoimmunity also reside at the plasma membrane. Among them, the copine BONZAI1 (BON1), which carries a C-terminal myristoylation site responsible for plasma membrane-association, suppressed autoimmunity by negatively regulating the $N L R$ gene SNC1 (Li et al. 2010; Yang and Hua 2004). The BON1associated proteins 1 and 2 were suggested to be general inhibitors of plant cell death (Yang et al. 2007). Furthermore, BON1 was shown to interact with two receptor-like kinases that contain leucine-rich repeats, namely the brassinosteroid signaling component BRI1-associated receptor kinase 1 (BAK1) and the regulator of resistance signaling pathways BAK1-interacting receptor-like kinase 1 at the plasma membrane (Wang et al. 2011). This interaction is fundamental for the negative regulation of $N L R$ genes to guarantee plant survival. The receptor-like protein SNC2 (suppressor of $n p r l$, constitutive 2) is a positive regulator of pathogen resistance, putatively by binding of pathogenassociated molecular patterns (PAMPs) (Zhang et al. 2010). The ankyrin-repeat protein BDA1 (bian da or 'becoming big' in Chinese) acts downstream of SNC2 and may also act at the plasma membrane, because it contains a putative C-terminal transmembrane domain (Yang et al. 2012). It will be interesting to test whether the plasma membrane-associated Ub ligase SAUL1 mediates immune responses independent of these factors or whether they act in concert.

This study identified SAUL1 as an important signaling component in plant immunity. In Figure 8, the working model proposes a role for SAUL1 in initiation of immune responses at the plasma membrane. In WT plants, SAUL1 inactivates an unknown positive regulator of immunity, either by degradation or regulation. This leads to inhibition of immunity upstream of the EDS1/PAD4 regulatory node. The SAUL1 pathway functions independently of NPR1 (Vogelmann et al. 2012). Such regulation leads to the suppression of SA accumulation and $P R$ gene expression, preventing autoimmunity. Future investigation will provide more information on the components that act up- and downstream of SAUL1 to regulate plant immunity.

\section{MATERIALS AND METHODS}

Plant material and growth conditions.

Arabidopsis thaliana seeds of saul1-1 mutants, its segregating WT, pad4-1, saul1-1 pad4-1, eds1-2, and sag101-1 mutants were sown on soil and were stratified in the dark at $4^{\circ} \mathrm{C}$ for $48 \mathrm{~h}$. Plants were grown in climate chambers (Weiss Klimatechnik
GmbH, Reiskirchen-Lindenstruth, Germany) or Arabidopsis growth cabinets (Percivals, CLF PlantClimatics GmbH, Wertingen, Germany) under long-day conditions (16 h light, $8 \mathrm{~h}$ dark) at various temperature, light, and humidity conditions, as indicated in each experiment. Temperature and relative humidity were monitored using a data logger (OM-EL-USB-2LCD-PLUS, OMEGA Engineering Inc., Deckenpfronn, Germany) and PFD was measured using a LI-250A light meter with a Quantum sensor (LI-COR Biosciences, Bad Homburg, Germany). The saul1-1 eds1-2 and saul1-1 sag101-1 double homozygous mutants were generated by crossing heterozygous saul $1-1$ plants with homozygous eds1-2 and sag101-1 lines, respectively. Homozygous double mutants were identified in the F2 and F3 generation by PCR using the SAUL1 specific primers $5^{\prime}$ TGAGGCCAATCAAATGATTTC- ${ }^{\prime}$ and $5^{\prime}$-TTTCCCCATTCA TGAGTGAAG-3' in combination with the T-DNA insertion (SALK) specific primer LBa1 (5'-TGGTTCACGTAGTGGGCCA TCG-3'), EDS1 specific primers 5'-ACACAAGGGTGATGCG AGACA-3', 5'-GGCTTGTATTCATCTTCTATCC-3' and 5'-G TGGAAACCAAATTTGACATTAG-3', SAG101 specific primers 5'-CACGCGTCCGAAGATCTTGGAGATACATA-3' and 5'-ACTTCCGGGTGTTCATAAACTCGGTCAAG-3' in combination with the $d S p m$ specific (SLAT) primer dSpm11 5'GGTGCAGCAAAACCCACACTTTTACTTC-3'.

\section{Pathogen infection experiments.}

P. syringae pv. maculicola ES4326 and H. arabidopsidis Noco2 infection experiments were carried out as described previously (Li et al. 2001). Briefly, leaves of 4-week-old plants grown for 4 weeks at $28^{\circ} \mathrm{C}, 80 \%$ relative humidity, and a PFD of



Fig. 8. Working model for SAUL1-mediated immunity. At the plasma membrane, SAUL1 is important to inactivate an unknown positive regulator (X) of plant defense by either mediating its ubiquitin-dependent degradation or regulation. This inactivation leads to the inhibition of EDS1/PAD4dependent immunity by an unidentified mechanism (?). The SAUL1 pathway is independent of NPR1 function. 
$90 \mu \mathrm{mol} \mathrm{m} \mathrm{m}^{-2} \mathrm{~s}^{-1}$ were infiltrated with $P$. syringae pv. maculicola ES4326 suspension at an optical density at $600 \mathrm{~nm}\left(\mathrm{OD}_{600}\right)=$ $0.001, P$. syringae pv. tomato $\mathrm{DC} 3000$ suspension at $\mathrm{OD}_{600}=$ 0.0002 , P. syringae pv. tomato DC3000 AvrRps4 suspension at $\mathrm{OD}_{600}=0.002$ at $22^{\circ} \mathrm{C}, 120 \mu \mathrm{mol} \mathrm{m} \mathrm{m}^{-2} \mathrm{~s}^{-1}$, and $60 \%$ relative humidity. Bacterial growth was quantified at days 0 and 3 or 4 after inoculation. For $H$. arabidopsidis Noco2, oomycete conidia spore suspension of 100,000 spores per milliliter in water was spray-inoculated onto 2-week-old seedlings. The plants were domed and were kept in an $18^{\circ} \mathrm{C}$ humid growth chamber (humidity $>80 \%$ ) for 7 days before oomycete growth quantification.

\section{Gene expression analysis by qPCR.}

For RNA analyses, above-ground tissue materials from a minimum of two plants per biological replicate were pooled. Total RNA was isolated using the innuPREP plant RNA kit (Analytik Jena AG, Jena, Germany). For synthesis of cDNAs, protocols of the QuantiTect reverse transcription kit (Qiagen, Hilden, Germany), using 500 ng of RNA per reaction, were followed. Quantitative PCR tests were performed using a Rotor-Gene Q (Qiagen) and the QuantiFast SYBR green PCR master mix (Qiagen). All samples were standardized to transcription levels of either $U B I$ or EIF1. Gene expression levels of the WT of the first sampling day of each experiment were set to 1 and expression levels of other genotypes and sampling days were given relative to this. Student's $t$ test analysis was used to determine significance of difference values. Primers for PCR amplification were 5'-GGCCTTGTATAATCCCTGATGAATA AG-3' and 5'-AAAGAGATAACAGGAACGGAAACATAGT-3' for $U B I, 5^{\prime}$-TGAGCACGCTCTTCTTGCTTTCA-3' and $5^{\prime}$ GGTGGTGGCATCCATCTTGTTACA-3' for EIF1, 5'-AGA TACGCGAGCACAACGCAAG-3' and 5'-TTTCTCGCCTCA TCCAACCACTC-3' for PAD4 (At3g52430), 5'-CGGCTAC CAACAACAACCAC-3' and 5'-CATTCCCGGAGGTAAGTT CG-3' for WRKY6 (At1g62300), 5'-TCCGTGACCTTGATC CTTTCTC-3' and 5'-TACCACCATAGGCACGAATCAG-3' for SID2 (At1g74710), 5'-CTCCCTCCAGGGTTCAGATTTC$3^{\prime}$ and $5^{\prime}$-GGAGACAGGGCATGGTTTAGAC-3" ${ }^{\prime \prime}$ for AtNAP (At1g69490), 5'-TACAACTACGCTGCGAACAC-3' and 5'ACACCTCACTTTGGCACATC-3' for PRl (At2g14610), as well as $5^{\prime}$-CATCGAGAACGCGGTTTCTG-3' and 5'-TGA GACGGAGGAGACGTATC-3' for PR2 (At3g57260).

\section{Determination of chlorophyll content and quantum yield.}

Chlorophyll fluorescence in the first true leaves of plants was measured 20 min after dark-adaptation using a portable chlorophyll fluorometer PAM-2500 (Heinz Walz GmbH, Effeltrich, Germany). The $F_{v} / F_{m}$ ratio was determined with the PamWin-3 software (Heinz Walz GmbH).

To determine chlorophyll content, leaf tissue was ground in liquid nitrogen, and $80 \%$ acetone was added to a final volume of $2 \mathrm{ml}$. After shaking for $30 \mathrm{~min}$ at $150 \mathrm{rpm}$ in the dark, the samples were centrifuged at 2,300 $\times g$ for $20 \mathrm{~min}$, and the supernatant was transferred to a new tube. The centrifugation was repeated at 7,600 $\times g$ for $10 \mathrm{~min}$ before measuring absorbance at $652 \mathrm{~nm}$ photometrically. The absorbance was normalized to a fresh weight of $20 \mathrm{mg}$ leaf tissue.

\section{TEM.}

In all experiments, the first true leaves of plants of the respective age were taken for TEM. The leaves were fixed with $2 \%$ glutaraldehyde and $2 \%$ paraformaldehyde (PFA) in $75 \mathrm{mM}$ cacodylate buffer ( $\mathrm{pH} 7.0$ ) for $5 \mathrm{~h}$ on ice, were washed three times with $75 \mathrm{mM}$ cacodylate buffer ( $\mathrm{pH} 7.0$ ), and were postfixed with $1 \%$ osmium tetroxide in $75 \mathrm{mM}$ cacodylate buffer (pH 7.0) overnight at $4^{\circ} \mathrm{C}$. The samples were washed three times with $75 \mathrm{mM}$ cacodylate buffer $(\mathrm{pH}$ 7.0) and were dehydrated through a series of graded acetone concentrations, 30 to $100 \%\left(4^{\circ} \mathrm{C}\right)$, two more changes of $100 \%$ at room temperature. The infiltration of the embedding medium and embedding was done as described (Spurr 1969). Ultrathin sections (70 to $80 \mathrm{~nm}$ ) were achieved with an ultramicrotome (Ultracut E, LeicaReichert-Jung, Nußloch, Germany) equipped with a diamond knife and were subsequently stained with uranyl acetate followed by lead citrate (Reynolds 1963). The sections were observed with a LEO 906 E TEM (LEO, Oberkochen, Germany) equipped with a multiscan CCD camera (Model 794) of Gatan using the Microscopy Suite software version 2.0.2 (Gatan, Munich, Germany) to visualize and analyze the image data.

\section{UMSP.}

Samples for UMSP analyses were prepared as described for TEM except for postfixation with osmium tetroxide. For UV-microspectrophotometry, we followed established protocols (Koch and Grünwald 2004; Koch and Kleist 2001). Briefly, semithin $(2 \mu \mathrm{m})$ sections were prepared by cutting the embedded material using an ultramicrotome equipped with a diamond knife (Ultracut S, Leica Reichert-Jung, Wetzlar, Germany). Subsequently, the sections were fixed on quartz slides, were immersed in a drop of non-UV absorbing glycerol and were covered with quartz cover slips. The topochemical analyses were conducted using a Zeiss UMSP 80 (Carl Zeiss AG) equipped with a scanning stage. The absorbance of the leave sections was measured at a constant wavelength of $278 \mathrm{~nm}$ (absorbance maximum of syringyl lignin) with a geometrical resolution of $0.25 \times 0.25 \mu \mathrm{m}$. The image profiles were determined with the scan program APAMOS (automatic-photometric-analysis of microscopic objects by scanning) (Carl Zeiss AG).

\section{Confocal laser scanning microscopy.}

For determination of callose by confocal laser scanning microscopy, the leaves were fixed with $2 \%$ PFA in $50 \mathrm{mM}$ microtubule stabilization buffer (MSB) $(100 \mathrm{mM}$ PIPES, 5 to $10 \mathrm{mM}$ EGTA, $5 \mathrm{mM} \mathrm{MgSO}$, $\mathrm{pH}$ 6.8) for $5 \mathrm{~h}$ on ice and were washed three times with $50 \mathrm{mM}$ MSB. The samples were then dehydrated through a series of graded ethanol concentrations, 30 to $90 \%, 20 \mathrm{~min}$ on ice, respectively, $100 \%$ for $30 \mathrm{~min}$ on ice, and $100 \%$ for $30 \mathrm{~min}$ at room temperature. The LR white resin (medium grade acrylic resin; London Resin Company Ltd, Reading, England) was infiltrated gradually, mixed with ethanol (1:2 for $1 \mathrm{~h}, 1: 1$ for $1 \mathrm{~h}, 2: 1$ for 1 to $2 \mathrm{~h}, 100 \%$ overnight, $100 \%$ for $5 \mathrm{~h}$, all steps at room temperature). The samples were filled in gelatin capsules and were cured at 40 to $50^{\circ} \mathrm{C}$ for $36 \mathrm{~h}$.

The embedded material was used to prepare semithin $(2 \mu \mathrm{m})$ sections, using an ultramicrotome equipped with a glass knife (Ultracut S). To detect callose, the sections were stained with $0.01 \%$ aniline blue in $150 \mathrm{mM} \mathrm{K}_{2} \mathrm{HPO}_{4}$ (pH 9.0) for $15 \mathrm{~min}$ in the dark and were rinsed with water. Images were captured with the Leica TCS SP8 confocal platform (Leica Microsystems, Wetzlar, Germany) using a 40× objective (HC PL APO CS2 $40 \mathrm{x} / 1.10$ water). Excitation wavelength of $405 \mathrm{~nm}$ (UV diode) and emission wavelength of 461 to $492 \mathrm{~nm}$ were used to observe fluorescence. Images were visualized and analyzed with Leica Application Suite X (Leica Microsystems).

\section{ACKNOWLEDGMENTS}

We thank E. Woelken for support with TEM, D. Paul for support with UMSP experiments, W. Hellmeyer for technical assistance, C. Reisdorff for help with PAM measurements, and J. Parker (MPI Köln) for supplying eds 1-2 and sag101-1 seeds. This work was supported by Natural Sciences and Engineering Research Council of Canada (NSERC) Discovery program and UBC Dewar Cooper Memorial Fund (to X. Li) and funded by the Deutsche Forschungsgemeinschaft (grant number HO 2234/4-3 to S. Hoth). 


\section{LITERATURE CITED}

Abramovitch, R. B., Janjusevic, R., Stebbins, C. E., and Martin, G. B. 2006. Type III effector AvrPtoB requires intrinsic E3 ubiquitin ligase activity to suppress plant cell death and immunity. Proc. Natl. Acad. Sci. U.S.A. 103:2851-2856

Angot, A., Peeters, N., Lechner, E., Vailleau, F., Baud, C., Gentzbittel, L., Sartorel, E., Genschik, P., Boucher, C., and Genin, S. 2006. Ralstonia solanacearum requires F-box-like domain-containing type III effectors to promote disease on several host plants. Proc. Natl. Acad. Sci. U.S.A. 103:14620-14625.

Bent, A. F., and Mackey, D. 2007. Elicitors, effectors, and $R$ genes: The new paradigm and a lifetime supply of questions. Annu. Rev. Phytopathol. 45:399-436

Berrocal-Lobo, M., Stone, S., Yang, X., Antico, J., Callis, J., Ramonell, K. M., and Somerville, S. 2010. ATL9, a RING zinc finger protein with E3 ubiquitin ligase activity implicated in chitin- and NADPH oxidasemediated defense responses. PLoS One 5:e14426.

Brooks, D. M., Hernández-Guzmán, G., Kloek, A. P., Alarcón-Chaidez, F., Sreedharan, A., Rangaswamy, V., Peñaloza-Vázquez, A., Bender, C.-L., and Kunkel, B. N. 2004. Identification and characterization of a well-defined series of coronatine biosynthetic mutants of Pseudomonas syringae pv. tomato DC3000. Mol. Plant-Microbe Interact. 17:162-174.

Callis, J. 2014. The ubiquitination machinery of the ubiquitin system. Arabidopsis Book 12:e0174.

Caño-Delgado, A., Penfield, S., Smith, C., Catley, M., and Bevan, M. 2003. Reduced cellulose synthesis invokes lignification and defense responses in Arabidopsis thaliana. Plant J. 34:351-362.

Cheng, Y. T., Germain, H., Wiermer, M., Bi, D., Xu, F., García, A. V., Wirthmueller, L., Després, C., Parker, J. E., Zhang, Y., and Li, X. 2009. Nuclear pore complex component MOS7/Nup88 is required for innate immunity and nuclear accumulation of defense regulators in Arabidopsis. Plant Cell 21:2503-2516.

Cheng, Y. T., Li, Y., Huang, S., Huang, Y., Dong, X., Zhang, Y., and Li, X. 2011. Stability of plant immune-receptor resistance proteins is controlled by SKP1-CULLIN1-F-box (SCF)-mediated protein degradation. Proc. Natl. Acad. Sci. U.S.A. 108:14694-14699.

Cho, S. K., Ryu, M. Y., Song, C., Kwak, J. M., and Kim, W. T. 2008 Arabidopsis PUB22 and PUB23 are homologous U-Box E3 ubiquitin ligases that play combinatory roles in response to drought stress. Plant Cell 20:1899-1914.

Coll, N. S., Epple, P., and Dangl, J. L. 2011. Programmed cell death in the plant immune system. Cell Death Differ. 18:1247-1256.

Drechsel, G., Bergler, J., Wippel, K., Sauer, N., Vogelmann, K., and Hoth, S. 2011. C-terminal armadillo repeats are essential and sufficient for association of the plant U-box armadillo E3 ubiquitin ligase SAUL1 with the plasma membrane. J. Exp. Bot. 62:775-785.

Dreher, K., and Callis, J. 2007. Ubiquitin, hormones and biotic stress in plants. Ann. Bot. (Lond.) 99:787-822.

Ellinger, D., Naumann, M., Falter, C., Zwikowics, C., Jamrow, T., Manisseri, C., Somerville, S. C., and Voigt, C. A. 2013. Elevated early callose deposition results in complete penetration resistance to powdery mildew in Arabidopsis. Plant Physiol. 161:1433-1444.

Ellis, C., Karafyllidis, I., Wasternack, C., and Turner, J. G. 2002. The Arabidopsis mutant cev1 links cell wall signaling to jasmonate and ethylene responses. Plant Cell 14:1557-1566.

Gepstein, S., and Glick, B. R. 2013. Strategies to ameliorate abiotic stressinduced plant senescence. Plant Mol. Biol. 82:623-633.

Goritschnig, S., Zhang, Y., and Li, X. 2007. The ubiquitin pathway is required for innate immunity in Arabidopsis. Plant J. 49:540-551.

Gou, M., Shi, Z., Zhu, Y., Bao, Z., Wang, G., and Hua, J. 2012. The F-box protein CPR1/CPR30 negatively regulates $\mathrm{R}$ protein $\mathrm{SNC} 1$ accumulation. Plant J. 69:411-420.

Hamann, T. 2015. The plant cell wall integrity maintenance mechanism-A case study of a cell wall plasma membrane signaling network. Phytochemistry $112: 100-109$

Hua, J., Grisafi, P., Cheng, S. H., and Fink, G. R. 2001. Plant growth homeostasis is controlled by the Arabidopsis BON1 and BAP1 genes. Genes Dev. 15:2263-2272.

Huang, Y., Minaker, S., Roth, C., Huang, S., Hieter, P., Lipka, V., Wiermer, M., and Li, X. 2014. An E4 ligase facilitates polyubiquitination of plant immune receptor resistance proteins in Arabidopsis. Plant Cell 26:485496

Ishikawa, K., Yamaguchi, K., Sakamoto, K., Yoshimura, S., Inoue, K., Tsuge, S., Kojima, C., and Kawasaki, T. 2014. Bacterial effector modulation of host E3 ligase activity suppresses PAMP-triggered immunity in rice. Nat. Commun. 5:5430.
Jambunathan, N., Siani, J. M., and McNellis, T. W. 2001. A humiditysensitive Arabidopsis copine mutant exhibits precocious cell death and increased disease resistance. Plant Cell 13:2225-2240.

Janjusevic, R., Abramovitch, R. B., Martin, G. B., and Stebbins, C. E. 2006. A bacterial inhibitor of host programmed cell death defenses is an E3 ubiquitin ligase. Science 311:222-226.

Jones, J. D., and Dangl, J. L. 2006. The plant immune system. Nature 444: 323-329.

Kachroo, A., and Kachroo, P. 2009. Fatty acid-derived signals in plant defense. Annu. Rev. Phytopathol. 47:153-176.

Kawasaki, T., Nam, J., Boyes, D. C., Holt, B. F., 3rd, Hubert, D. A., Wiig, A., and Dangl, J. L. 2005. A duplicated pair of Arabidopsis RING-finger E3 ligases contribute to the RPM1- and RPS2-mediated hypersensitive response. Plant J. 44:258-270.

Kim, C., Meskauskiene, R., Zhang, S., Lee, K. P., Lakshmanan Ashok, M. Blajecka, K., Herrfurth, C., Feussner, I., and Apel, K. 2012. Chloroplasts of Arabidopsis are the source and a primary target of a plant-specific programmed cell death signaling pathway. Plant Cell 24:3026-3039.

Koch, G., and Grünwald, C. 2004. Application of UV microspectrophotometry for the topochemical detection of lignin and phenolic extractives in wood fibre cell walls. Pages 119-130 in: Wood Fibre Cell Walls: Methods to Study their Formation, Structure and Properties. U. Schmitt, P. Anderer, J. R. Barnett, A. M. C. Emons, G. Jeronimidis, P. Saranpäa, and S. Stanzl-Tschegg eds. Swedish University of Agricultural Sciences, Uppsala, Sweden.

Koch, G., and Kleist, G. 2001. Application of scanning UV microspectrophotometry to localise lignins and phenolic extractives in plant cell walls. Holzforschung 55:563-567.

Li, W., Ahn, I. P., Ning, Y., Park, C. H., Zeng, L., Whitehill, J. G., Lu, H., Zhao, Q., Ding, B., Xie, Q., Zhou, J. M., Dai, L., and Wang, G. L. 2012 The U-Box/ARM E3 ligase PUB13 regulates cell death, defense, and flowering time in Arabidopsis. Plant Physiol. 159:239-250.

Li, X., Clarke, J. D., Zhang, Y., and Dong, X. 2001. Activation of an EDS1mediated $R$-gene pathway in the sncl mutant leads to constitutive, NPR1-independent pathogen resistance. Mol. Plant-Microbe Interact. 14:1131-1139.

Li, Y., Gou, M., Sun, Q., and Hua, J. 2010. Requirement of calcium binding, myristoylation, and protein-protein interaction for the copine BON1 function in Arabidopsis. J. Biol. Chem. 285:29884-29891.

Lin, S. S., Martin, R., Mongrand, S., Vandenabeele, S., Chen, K. C., Jang, I. C., and Chua, N. H. 2008. RING1 E3 ligase localizes to plasma membrane lipid rafts to trigger FB1-induced programmed cell death in Arabidopsis. Plant J. 56:550-561.

Lippold, F., vom Dorp, K., Abraham, M., Hölzl, G., Wewer, V., Yilmaz, J. L., Lager, I., Montandon, C., Besagni, C., Kessler, F., Stymne, S., and Dörmann, P. 2012. Fatty acid phytyl ester synthesis in chloroplasts of Arabidopsis. Plant Cell 24:2001-2014.

Lu, D., Lin, W., Gao, X., Wu, S., Cheng, C., Avila, J., Heese, A., Devarenne, T. P., He, P., and Shan, L. 2011. Direct ubiquitination of pattern recognition receptor FLS2 attenuates plant innate immunity. Science 332:1439-1442.

Malinovsky, F. G., Fangel, J. U., and Willats, W. G. 2014. The role of the cell wall in plant immunity. Front. Plant Sci. 5:178.

Monaghan, J., Xu, F., Gao, M., Zhao, Q., Palma, K., Long, C., Chen, S., Zhang, Y., and Li, X. 2009. Two Prp19-like U-box proteins in the MOS4associated complex play redundant roles in plant innate immunity. PLoS Pathog. 5:e1000526.

Nishimura, M. T., Stein, M., Hou, B. H., Vogel, J. P., Edwards, H., and Somerville, S. C. 2003. Loss of a callose synthase results in salicylic acid-dependent disease resistance. Science 301:969-972.

Nomura, H., Komori, T., Uemura, S., Kanda, Y., Shimotani, K., Nakai, K., Furuichi, T., Takebayashi, K., Sugimoto, T., Sano, S., Suwastika, I. N., Fukusaki, E., Yoshioka, H., Nakahira, Y., and Shiina, T. 2012. Chloroplast-mediated activation of plant immune signalling in Arabidopsis. Nat. Commun. 3:926.

Ochsenbein, C., Przybyla, D., Danon, A., Landgraf, F., Göbel, C., Imboden, A., Feussner, I., and Apel, K. 2006. The role of EDS1 (enhanced disease susceptibility) during singlet oxygen-mediated stress responses of Arabidopsis. Plant J. 47:445-456.

Pazhouhandeh, M., Dieterle, M., Marrocco, K., Lechner, E., Berry, B., Brault, V., Hemmer, O., Kretsch, T., Richards, K. E., Genschik, P., and Ziegler-Graff, V. 2006. F-box-like domain in the polerovirus protein P0 is required for silencing suppressor function. Proc. Natl. Acad. Sci. U.S.A. 103:1994-1999.

Raab, S., Drechsel, G., Zarepour, M., Hartung, W., Koshiba, T., Bittner, F., and Hoth, S. 2009. Identification of a novel E3 ubiquitin ligase that is required for suppression of premature senescence in Arabidopsis. Plant J. 59:39-51.

Reynolds, E. S. 1963. The use of lead citrate at high $\mathrm{pH}$ as an electronopaque stain in electron microscopy. J. Cell Biol. 17:208-212. 
Salt, J. N., Yoshioka, K., Moeder, W., and Goring, D. R. 2011. Altered germination and subcellular localization patterns for PUB44/SAUL1 in response to stress and phytohormone treatments. PLoS One 6: e21321.

Samuel, M. A., Mudgil, Y., Salt, J. N., Delmas, F., Ramachandran, S., Chilelli, A., and Goring, D. R. 2008. Interactions between the S-domain receptor kinases and AtPUB-ARM E3 ubiquitin ligases suggest a conserved signaling pathway in Arabidopsis. Plant Physiol. 147:2084-2095.

Schrammeijer, B., Risseeuw, E., Pansegrau, W., Regensburg-Tuïnk, T. J., Crosby, W. L., and Hooykaas, P. J. 2001. Interaction of the virulence protein VirF of Agrobacterium tumefaciens with plant homologs of the yeast Skp1 protein. Curr. Biol. 11:258-262.

Singer, A. U., Schulze, S., Skarina, T., Xu, X., Cui, H., Eschen-Lippold, L., Egler, M., Srikumar, T., Raught, B., Lee, J., Scheel, D., Savchenko, A., and Bonas, U. 2013. A pathogen type III effector with a novel E3 ubiquitin ligase architecture. PLoS Pathog. 9:e1003121.

Spurr, A. R. 1969. A low-viscosity epoxy resin embedding medium for electron microscopy. J. Ultrastruct. Res. 26:31-43.

Stegmann, M., Anderson, R. G., Ichimura, K., Pecenkova, T., Reuter, P., Zársky, V., McDowell, J. M., Shirasu, K., and Trujillo, M. 2012. The ubiquitin ligase PUB22 targets a subunit of the exocyst complex required for PAMP-triggered responses in Arabidopsis. Plant Cell 24: 4703-4716.

Trujillo, M., Ichimura, K., Casais, C., and Shirasu, K. 2008. Negative regulation of PAMP-triggered immunity by an E3 ubiquitin ligase triplet in Arabidopsis. Curr. Biol. 18:1396-1401.

Tzfira, T., Vaidya, M., and Citovsky, V. 2004. Involvement of targeted proteolysis in plant genetic transformation by agrobacterium. Nature 431:87-92.

Underwood, W. 2012. The plant cell wall: A dynamic barrier against pathogen invasion. Front. Plant Sci. 3:85.

Üstün, S., Bartetzko, V., and Börnke, F. 2013. The Xanthomonas campestris type III effector XopJ targets the host cell proteasome to suppress salicylic-acid mediated plant defence. PLoS Pathog. 9:e1003427.

Üstün, S., König, P., Guttman, D. S., and Börnke, F. 2014. HopZ4 from Pseudomonas syringae, a member of the HopZ type III effector family from the YopJ superfamily, inhibits the proteasome in plants. Mol. PlantMicrobe Interact. 27:611-623.

Van Hautegem, T., Waters, A. J., Goodrich, J., and Nowack, M. K. 2015. Only in dying, life: Programmed cell death during plant development. Trends Plant Sci. 20:102-113.

Vierstra, R. D. 2009. The ubiquitin-26S proteasome system at the nexus of plant biology. Nat. Rev. Mol. Cell Biol. 10:385-397.

Vogelmann, K., Drechsel, G., Bergler, J., Subert, C., Philippar, K., Soll, J., Engelmann, J. C., Engelsdorf, T., Voll, L. M., and Hoth, S. 2012. Early senescence and cell death in Arabidopsis saull mutants involves the PAD4-dependent salicylic acid pathway. Plant Physiol. 159:1477-1487.

Vogelmann, K., Subert, C., Danzberger, N., Drechsel, G., Bergler, J., Kotur, T., Burmester, T., and Hoth, S. 2014. Plasma membrane-association of SAUL1-type plant U-box armadillo repeat proteins is conserved in land plants. Front. Plant Sci. 5:37.

Wagner, D., Przybyla, D., Op den Camp, R., Kim, C., Landgraf, F., Lee, K. P., Würsch, M., Laloi, C., Nater, M., Hideg, E., and Apel, K. 2004. The genetic basis of singlet oxygen-induced stress responses of Arabidopsis thaliana. Science 306:1183-1185.

Wang, Y., Zhang, Y., Wang, Z., Zhang, X., and Yang, S. 2013. A missense mutation in CHS1, a TIR-NB protein, induces chilling sensitivity in Arabidopsis. Plant J. 75:553-565.

Wang, Z., Meng, P., Zhang, X., Ren, D., and Yang, S. 2011. BON1 interacts with the protein kinases BIR1 and BAK1 in modulation of temperaturedependent plant growth and cell death in Arabidopsis. Plant J. 67:1081-1093.

Wiermer, M., Feys, B. J., and Parker, J. E. 2005. Plant immunity: The EDS1 regulatory node. Curr. Opin. Plant Biol. 8:383-389.

Yang, C. W., González-Lamothe, R., Ewan, R. A., Rowland, O., Yoshioka, H., Shenton, M., Ye, H., O’Donnell, E., Jones, J. D., and Sadanandom, A. 2006. The E3 ubiquitin ligase activity of arabidopsis PLANT U-BOX17 and its functional tobacco homolog ACRE276 are required for cell death and defense. Plant Cell 18:1084-1098.

Yang, H., Yang, S., Li, Y., and Hua, J. 2007. The Arabidopsis BAP1 and $B A P 2$ genes are general inhibitors of programmed cell death. Plant Physiol. 145:135-146.

Yang, S., and Hua, J. 2004. A haplotype-specific resistance gene regulated by BONZAI1 mediates temperature-dependent growth control in Arabidopsis. Plant Cell 16:1060-1071.

Yang, Y., Zhang, Y., Ding, P., Johnson, K., Li, X., and Zhang, Y. 2012. The ankyrin-repeat transmembrane protein BDA1 functions downstream of the receptor-like protein SNC2 to regulate plant immunity. Plant Physiol. 159:1857-1865.

Zbierzak, A. M., Porfirova, S., Griebel, T., Melzer, M., Parker, J. E., and Dörmann, P. 2013. A TIR-NBS protein encoded by Arabidopsis chilling sensitive 1 ( $C H S 1)$ limits chloroplast damage and cell death at low temperature. Plant J. 75:539-552.

Zhang, Y., Yang, Y., Fang, B., Gannon, P., Ding, P., Li, X., and Zhang, Y. 2010. Arabidopsis snc2-1D activates receptor-like protein-mediated immunity transduced through WRKY70. Plant Cell 22:3153-3163.

Zurbriggen, M. D., Carrillo, N., Tognetti, V. B., Melzer, M., Peisker, M., Hause, B., and Hajirezaei, M. R. 2009. Chloroplast-generated reactive oxygen species play a major role in localized cell death during the nonhost interaction between tobacco and Xanthomonas campestris pv. vesicatoria. Plant J. 60:962-973. 